\title{
Alaşehir Alt Havzasının (Gediz Havzası, Batı Anadolu) Nem Değişimi Yöntemine Göre Yeraltısuyu Besleniminin Değerlendirilmesi
}

\section{Evaluation of the Groundwater Recharge Capacity of Alaşehir Sub-Basin (Gediz Basin, Western Anatolia) via Soil Moisture Variation Method}

\author{
Seda Durukan $1^{*} \oplus$, Celalettin Şimşek ${ }^{2}{ }^{\oplus}$, Serhat Tonkul ${ }^{3}{ }^{\circledR}$, Alper Baba ${ }^{4}(0$, \\ Gökmen Tayfur ${ }^{4}$ (b) \\ ${ }^{1}$ Manisa Celal Bayar Üniversitesi Manisa Teknik Bilimler MYO İnşaat Bölümü, Manisa, TÜRKIYE \\ ${ }^{2}$ Dokuz Eylül Üniversitesi Torbalı MYO İnşaat Bölümü, İzmir, TÜRKIYE \\ 3 İzmir Yüksek Teknoloji Enstitüsü Mühendislik ve Fen Bilimleri Enstitüsü, İzmir, TÜRKIYE \\ 4 İzmir Yüksek Teknoloji Enstitüsü Mühendislik Fakültesi İnşaat Mühendisliği Bölümü, İzmir, TÜRKIYYE \\ Sorumlu Yazar / Corresponding Author*: seda.durukan@cbu.edu.tr \\ Atıf sekli/How to cite: DURUKAN, S., SIMSEK, C., TONKUL, S., BABA, A., TAYFUR, G. (2021). Alaşehir Alt Havzasının (Gediz Havzası, Batı \\ Anadolu) Nem Değişimi Yöntemine Göre Yeraltısuyu Besleniminin Değerlendirilmesi. DEUFMD, 23(67), 11-23. \\ Öz
}

Gediz havzası Ege Bölgesinin en önemli havzalarından biridir. Çalıșma alanı Gediz havzası içerisinde bulunan Alaşehir alt havzasıdır. Bu çalışma kapsamında Alaşehir alüvyon akifere çok sayıda araştırma kuyusu açılmış olup, araştırma kuyularında zemin karakterizasyonu belirlenmiş ve bazı kuyulara da zemin nem sensörleri konumlandırılarak yeraltısuyu beslenimi hesaplanmıștır. Doygun olmayan bölgedeki zeminlerde nem değişim yöntemi ile yağıștan sonra zemin nem değişimleri belirlenerek yağıștan beslenme miktarı tespit edilebilmektedir. Bu kapsamda alüvyon akifere 5 farklı noktada özel açılan kuyularda 5, 10 ve $15 \mathrm{~m}$ derinliklerde nem sensörleri vasıtası ile zemin nemi, sıcaklığı ve tuzluluğu ölçülmüştür. Çalışma alanında seçilen kuyularda zeminin suya doygun olmayan bölgesinde gerçekleștirilen hacimsel su içeriklerine göre mevsimsel değişiklikleri ortaya konulmuş ve yağıştan kaynaklanan beslenme miktarı belirlenmiştir. Elde edilen ölçümler sonucunda, çalışma alanındaki alüvyon akiferdeki yeraltısuyu beslenimi en az 40,81 ile en çok 77,12 mm olacak şekilde, ortalama olarak da 56,83 mm hesaplanmıştır. Ayrıca, ilk kez derin kuyular vasıtası ile yeraltısuyu besleniminde kullanılan zemin nem değişim yönteminin limitasyonları da bu çalışma kapsamında tartışılmıştır.

Anahtar Kelimeler: Beslenim, Nem Sensörleri, Yeraltısuyu, Vadoz zon

\begin{abstract}
Gediz basin is one of the most important basins in the Aegean Region of Turkey. The related study area, Alașehir, is a sub-basin of Gediz basin. In this respect, many investigations and/or monitoring wells in the Alaşehir alluvial aquifer had been drilled, soil characterization was done and groundwater recharge was calculated by using soil moisture sensors. The groundwater recharge can be calculated by using soil moisture variation for soils located in the vadose zone by recording the
\end{abstract}




\section{DEÜ FMD 23(67), 11-23, 2021}

soil moisture changes after rainfall. Thus, soil moistures, temperature, and salinity measurements were recorded in 5 selected wells at varying depths of 5, 10 and $15 \mathrm{~m}$ via soil moisture sensors. In this study, the measurements of volumetric water contents of selected wells at varying depths of the vadose zone were obtained and presented, the assessment of the variation of the data with seasonal changes was done and recharge values were determined. Based on the recorded data, the groundwater recharge of the study area was calculated to vary between 40.81 and $77.12 \mathrm{~mm}$ with an average of $56.83 \mathrm{~mm}$. In addition, the operating method of the soil moisture sensors, the process of locating the sensors in the wells and the limitations of the method were explained.

Keywords: Recharge, Moisture Sensors, Groundwater, Vadose Zone

\section{Giriş}

Dünya üzerinde buzullarda yer alan su kütleleri de dahil olmak üzere tatlı su rezervi $\% 2.5^{\prime}$ dir. $\mathrm{Bu}$ suyun \%35'i ise tatlı yeraltısuyu kaynaklarını olușturur [1]. Akiferden çekilen yeraltısuyunun $\%$ 60'ı tarımsal, \%20'si sanayi ve geri kalan kısmı ise içme suyu amaçlı olarak kullanılmaktadır. Bununla birlikte, birçok kurak ve yarı kurak bölgede ise canlıların içme suyu gereksinimi çoğunlukla yeraltısuyuna bağımlıdır. Su sıkıntısının çekildiği ve bölgesel ekonominin yeraltısuyuna bağlı olduğu yarı kurak ve kurak alanlarda sosyo-ekonomi dengesi bozulmakta ve insanlar göçe maruz kalmaktadır [2-4].

Türkiye iklim ve coğrafik özellikleri dikkate alındığında yarı kurak ve kurak iklim tipine sahip bir kuşakta olup, su azlığı problemi yaşayan bir bölgede yer almaktadır [5]. Ülkemizde nüfus dağılımı incelendiğinde ekonomik olarak su talebinin oldukça yoğun olduğu alanları da aynı zamanda tarımsal ve sanayi alanlarının olduğu bölgeler oluşturmaktadır. Türkiye'nin topoğrafik özellikleri dikkate alındığında 25 su havzası olmasına rağmen, bu su havzaları içerisinde nüfus büyük oranda Marmara ve Ege Bölgesinde yoğunlaşmaktadır. Bu alanlarda sulama, sanayi ve içme suyu tüketimi büyük oranda yeraltısuyuna bağımlıdır. Așırı yeraltısuyu tüketimi, yeraltısuyu seviyelerinde önemli düşümlere neden olmakta ve bahsedilen bölgelerde kurak dönemlerde önemli su problemleri yaşanmaktadır [6-9]. Ege ve Marmara Bölgesinin de içinde bulunduğu büyük nehir havzalarını oluşturan Kuzey Ege, Gediz, Büyük ve Küçük Menderes havzalarındaki yeraltısuyu aşırı çekim baskısı altındadır [9]. Yeraltısuyu kaynakları yenilenebilir kaynaklar olmasına karşın, aşırı çekim baskısı nedeniyle akiferde yeterince depolanamamakta ve depolama rezervi sürekli olarak azalmaktadır. $\mathrm{Bu}$ bağlamda son yllarda yeraltısuyunun sürdürülebilir verimliliğinin arttırılması için kalite ve miktarın belirlenmesine yönelik olarak detaylı hidrojeolojik çalıșmalar yoğunlașmıștır $[6,10]$. Bunlara ek olarak, Nehir Havza Yönetim planlama çalışmalarının tüm havzalarda tamamlanmasına gayret edilmektedir [9]. Ayrıca, su kaynaklarındaki aşırı tüketimin ve kirlilik boyutunun önüne geçilmesi için yasal düzenlemeler yapılmaktadır $[11,12]$.

Yeraltısuyunun araștırılması ve yönetim planlarının oluşturulması, ancak bölgenin hidrolojik ve hidrojeolojik özelliklerinin gerçekçi bir şekilde ortaya konulması, yeraltısuyunun bulunduğu akifer sistemin karakteristiğinin belirlenmesi, beslenme ve boșalım mekanizmasının anlaşılması ile mümkündür. Bütün bu araştırmaların içerisinden belirlenmesi en güç parametreleri beslenme ve boşalım miktarının saptanması oluşturmaktadır. Yeraltısuyunun beslenme miktarının belirlenmesine yönelik somut yöntemlerin geliştirilmemesi ve bir standarda oturtulmaması nedeniyle yeraltısuyu beslenim miktarının belirlenmesi hidrojeolojik çalışmalarda ölçülmesi ve hesaplanması en güç parametrelerden birisini olușturur [13].

Literatürde çok farklı yöntemlerle beslenme değerinin belirlenmesine yönelik çalıșma mevcuttur. Doymamış ve doygun bölgede beslenme miktarının belirlenmesine yönelik farklı yöntemler kullanılmaktadır [13-16]. Bu yöntemlerin özeti Tablo 1'de sunulmuştur. Genel olarak kullanılan yöntemler; bütçe modeli, fiziksel ölçüm yöntemleri, izleyici ve kimyasal izleme teknikleri (duraylı izotoplar ve çevresel izleyiciler), nümerik modelleme çalışmaları ve yeraltısuyu seviye değișim yöntemleridir [17]. Son yillarda vadoz zondaki toprak nemi ölçümleri yapılarak yeraltısuyu beslenmesinin belirlenmesinde dolaylı yöntemler kullanılmaktadır [18]. Dolaylı yöntemlerde, toprağın belirli fiziksel ve fizikokimyasal özelliklerinin su miktarına bağlı olarak değişimi esas alınır [19]. Bunun için toprağın belli 
DEÜ FMD 23(67), 11-23, 2021

derinliklerine yerlestirilen sensörlerle toprak içerisindeki zemin nemi, sıcaklığı ve tuzluluğu gibi parametrelerin değişimi izlenir. Bu yöntem genel olarak tarımsal çalışmalarda kullanılan ve toprak nemini arazide zamana bağlı olarak izlenmesi sağlanmaktadır.

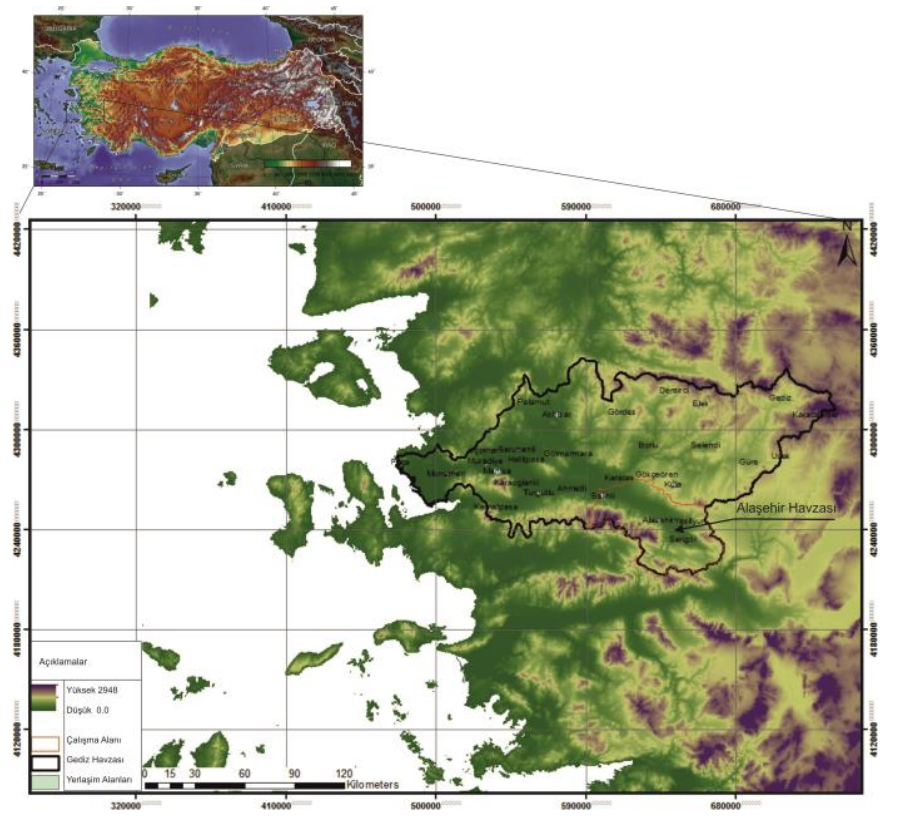

Şekil 1. Çalışma alanının yer bulduru haritası

Son zamanlarda ise bu yöntem ile yeraltısuyu beslenmesinin belirlenmesinde kullanılmaya başlanmıştır. Özellikle yağışlardan sonra veya sulama suyundan sonra zemin nemindeki değişimler belirlenerek yağışın ne kadarlık bir etkisi olduğu zemin nemindeki hacimsel değişimden belirlenebilmektedir $[20,21]$. Bu sistem ile zemin nemindeki değișim anlık olarak izlenmekte ve yağıș ile ilișkisi değerlendirilebilmektedir.

Tablo 1. Kurak ve Yarı Kurak İklim Bölgelerinde Uygulanan Yeraltısuyu Beslenme Teknikleri [14].

\begin{tabular}{ll}
\hline & Kurak-Yarı Kurak Bölgeler için \\
Hidrolojik Zon & Beslenme Teknikleri \\
\hline \multirow{3}{*}{ Yüzey Suyu } & Kanal Su Bütçesi \\
& Sizma Ölçerler \\
& İzleyiciler \\
& İzotop İzleyiciler \\
& Yüzeysel Akış Modeli \\
\hline \multirow{3}{*}{ Doymamış Bölge } & Lizimetre \\
& Darcy Yasası \\
& İzotop ve Çevresel İzleyiciler \\
& Yeraltısuyu Akım Modellemesi \\
\hline \multirow{3}{*}{ Doygun Bölge } & İzotop ve Çevresel İzleyiciler \\
& Yeraltısuyu Akım Modellemesi \\
& Yeraltısuyu Seviye Değişim Modeli \\
\hline
\end{tabular}

Bu çalıșmanın ana hedefi de, Gediz havzasının bir alt havzası olan Alaşehir havzasındaki akiferin zemin karakterizasyonunu ortaya koymak ve yeraltı suyu beslenimini nem ölçüm yöntemi ile tespit etmektir. Proje sahasının sınırları, DSI hidrojeolojik etüt çalışmaları kapsamında 1:25000 ölçekli Harita Genel Komutanlığı (HGK) haritaları, bu haritalardan oluşturulan sayısal yükselti modeli ve akarsu akaçlama ağ katmanları kullanılarak hazırlanmıștır. Alașehir Cayı'nın Gediz Nehri'ne karıștığı noktaya kadar olan kısmı ve buna ait su toplama havzası Alaşehir Alt Havzası olarak tanımlanmıştır [7]. Bu bağlamda bu proje kapsamında Alașehir alt havzası drenaj alanı proje sahasını olușturmaktadır. Gediz havzasının ve Alașehir havzasının konumu Şekil 1'de sunulmuștur.

\section{Materyal ve Metot}

İlk aşamada, akifer karakterizasyon çalışmaları yapılmıştır. Bu kapsamda, 24 farklı noktada toplam derinliği 1300 metreden fazla olan araștırma sondaj kuyuları açılmıştır. Buna ek olarak, proje sahasında 5 noktada zemin nem sensörünün yerleştirilmesi için kuyular 
DEÜ FMD 23(67), 11-23, 2021

açılmıștır. Zemin nem sensörü bir uzun çatal şeklinde hassas bir cihazdır. Zemin nem sensörlerinin yerleștirildiği kuyuların havzadaki dağılımı Şekil 2'de sunulmuştur. Seçilen 5 noktanın isimleri ise Çağlayan (CY), Çavuşlar (CV), Hacılı (HC), Tepeköy (TP) ve Tirazlı (TR) olarak Șekil 2 üzerinde işaretlenmiștir. Her noktada ise derinlikleri 5,10 ve 15 m olan ve uzaklıkları $1 \mathrm{~m}$ 'den daha yakın olan 3 adet kuyu açılmıştır (Şekil 3). Noktalara eklenen 1 sayısı ise sensörleri ifade etmektedir (Ör: CY-1 = Çağlayan noktası sensörü). Toplamda zemin nem sensörü için 15 adet kuyu açılmıştır. Bu kuyuların en derin olanı araștırma kuyusu olarak tasarlanmıș ve araştırma kuyusu açım prosedürüne göre delinmiştir. Kuyudan karot alınmıș ve geçirgenlik deneyleri yapılmıştır. Bu kuyuların içerisinde araştırma kuyularında kullanılan 70 mm PVC boru kullanılmıştır. Kuyu içerisine boru yerleştirirlerken PVC borunun ağzı açlk olarak kuyu borulanmıștır.

Nem sensörlerinin kalibrasyonu için üretici firma tarafından verilen 15 adet farklı toprak sınıfı için belirlenmiş eğriler kullanılarak kalibre edilmiştir.

$\mathrm{Bu}$ sensörler genelde hendek çukurlarına el ile yerleştirilmektedir. Ancak bu çalıșma kapsamında 5, 10 ve $15 \mathrm{~m}$ derinliklerde açılan kuyu tabanlarına yerleştirilmiştir.

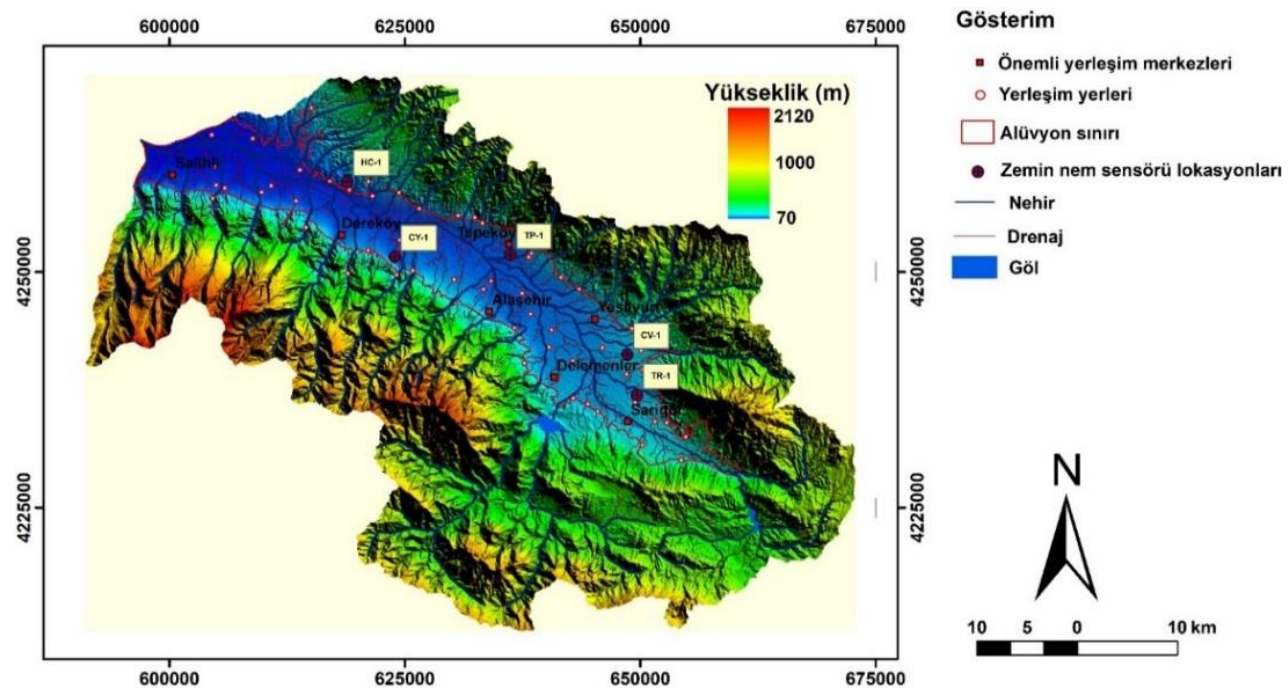

Şekil 2. Zemin nem sistemi için açılan kuyuların Alaşehir havzasındaki dağılımları

Catallar killi ve siltli zeminlere rahat batırılırken, çakıllı zeminlerde zorlukla karşılanmıștır. Bu nedenle çakıllı zeminlerde çatalların zarar görmemesi için farklı bir çubuk zemine batırılarak kontrol edilmiștir. Bu cihazı kuyu tabanına yerleștirmek için birer metrelik borular kullanılarak zemin nem sensörü kuyu tabanına hassas bir șekilde batırılmıștır. Daha sonra borular kuyudan çıkartılmıştır. Yan yana açılan kuyulara yerleștirilen ve genel olarak 5, 10, $15 \mathrm{~m}$ derinliklere konumlandırılan sensörler merkezi bir veri kaydediciye bağlanmıștır. Bunun için toprak altından kuyular arası bağlantıyı sağlayacak PVC borular döşenmiştir. Bu sayede cihazın dikkat çekici veya zarar görecek durumlardan korunmuştur. Bu kaydedicinin güç beslenimi için $12 \mathrm{~V}$ bir akü yerleştirilerek sistem çalışır hale getirilmiștir. Sistem $50 \mathrm{~m}$ yakınına kadar bilgisayar ile bağlantı kurmaya olanak vermektedir. Yani bu sistemin yanına gelince istenildiği takdirde araç içerisinden de veriler kontrol edilebilmekte, veriler bilgisayara indirilebilmektedir. Bu ölçüm sistemleri sondaj kuyularına yerleștirilerek derinliğe bağlı zemin nemi, sıcaklığı ve tuzluluğu kaydedilmiștir. Ayrıca ilk bir aylık süre zarfında kuyuların su alıp almadığı kontrol edilmiştir. Her ay düzenli olarak veriler alınmıș ve cihazlar kontrol edilmiştir. Bazı verilerin zemin sınıfına bağlı olarak özellikle iri daneli zeminler salınıml olması nedeni ile değerler normalize edilmiştir. 


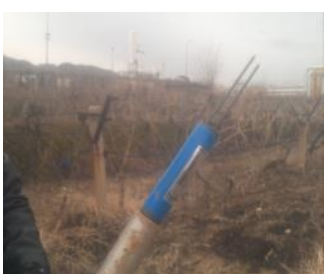

(a)

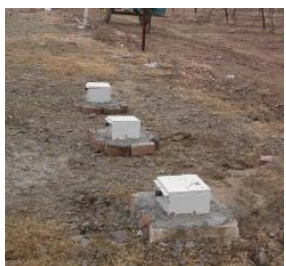

(b)
Şekil 3. Nem sensörleri (a) ve farklı derinliklerde konumlandırması (b)

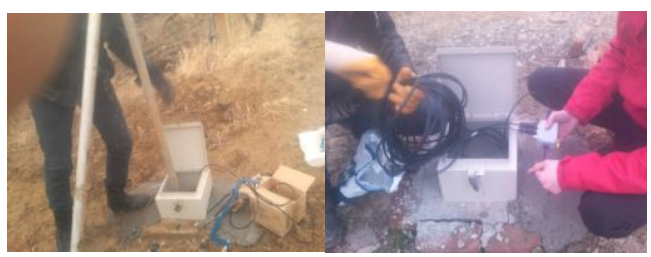

Şekil 4. Nem sensörlerinin kuyu montajı

Doygun olmayan yani vadoz zondaki zemin nem değișim yöntemi kullanılarak yağıștan sonra zemin nem değişimleri belirlenerek yağıștan beslenme miktarı belirlenebilmektedir [22, 23]. Zemin nemi yağıștan sonra yüzeysel akış ve buharlaşmadan arta kalan kısım süzülmeye geçerek graviteye bağlı olarak aşağı doğru yani doygun kuşağa doğru hareket etmektedir (Şekil 5). Yüzeye yakın olan yeraltısuyu seviyelerinden genel olarak ülkemizde $0-3 \mathrm{~m}$ arasında yeraltısuyundan buharlaşma olacağı kabul edilmektedir [7]. Ancak çalıșma alanında konumlandırılan zemin nem sensörlerinin bulunduğu alanlarda su derinliği 20-30 m arasında değişmektedir. $\mathrm{Bu}$ bağlamda yeraltısuyu buharlașması burada ihmal edilmektedir. Burada konumlandırılan 5, 10 ve $15 \mathrm{~m}$ derinliklerdeki zemin nem oranları doğrudan süzülmeye geçen doygun olmayan kuşaktaki oranları ifade etmektedir. Zemin nem sensörü verileri kullanılarak hacimsel değișim Denklem 1 ile belirlenebilmektedir [23].

$$
V=\sum_{n=1}^{M}\left(\Theta_{n} \Delta Z n\right)
$$

Burada $\mathrm{n}$, probe sayısı, $\theta_{n}$ hacimsel zemin nemi, $\Delta Z n$ ise düșey profildeki derinlikleri ifade etmektedir. Burada elde edilen düșey nem miktarlarındaki değișimler belirlenerek yağış sonrası zemin nemindeki değișim belirlenmekte ve yağışa oranla ne kadar değişim olduğu ortaya konulabilmektedir. $\mathrm{Bu}$ bağlamda yapılan çalıșmada özellikle kurak dönem sonu olan Eylül 2017 tarihi ile 2018 Mayıs arasındaki zemin nem verileri ve yağıșları kullanılmıştır. Eylül ayındaki en düşük zemin nemi ve yağıș sonrası en yüksek zemin nemleri belirlenerek aylık yağıșa oranla değişimleri ortaya konulmuștur.

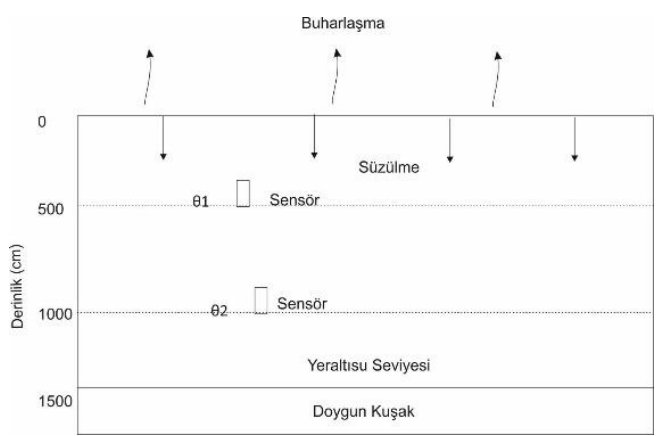

Şekil 5. Zemin nem değișimi için oluşturulan dikey kesit

\section{Bulgular}

\subsection{Proje sahası ve jeolojisi}

Proje sahası tipik bir graben yapısındadır. Havzanın orta kesimleri çöküntü alanlarını batı, doğu ve güneydoğu kesimleri yükseltiler ile çevrelenmiştir. Havzanın kuzeybatı kesimi açı olup Salihli havzası ile birleşmektedir. Proje sahası deniz seviyesinden 83 ile 2155 m arasında değişmekte olup, düşük kotlarda geniş Alaşehir ovası yer almaktadır. Yüksek kesimlerden ise Bozdağ ve Seyran dağları ile çevrilidir. Alt havza genelinde güneydoğu-kuzeybatı yönlü bir drenaj söz konusudur. Alaşehir Ovasını çevreleyen yükseltilerden gelen drenaj ağları ovada Alaşehir Çayı'na katılarak havzanın kuzeybatısında Gediz Nehrine birleşmektedir. Proje sahasının batısında Avşar Çayı üzerinde Avşar Barajı, güneyinde Çamköy Deresi üzerinde ise Derbent barajı yer almaktadır. Her iki baraj Alaşehir ovasında tarımsal sulama için kullanılmaktadır. Proje sahasının batı kesimleri doğu kesimlerine göre daha yüksek alanları oluşturmaktadır. Bu nedenle daha sık ve derin akaçlama ağları batı kesimlerde gelişmiştir. Akaçlama ağlarının gelişmesini alanın jeolojik yapısı ve yapısal özellikleri kontrol etmektedir. Proje sahası içerisinde yer alan önemli yerleşim alanları Alaşehir ovasında yani alüvyonel alanlarda gelişmiștir. Çalıșma alanına ait jeoloji haritası Șekil 6'da sunulmuștur. Havzada Miyosen öncesi temel kayalarını Menderes Masifi'ne ait metamorfik kayalar oluşturur. Havzanın Miyosen-Kuvaterner tortul dolgusunu Alaşehir formasyonu ve güncel alüvyonlar oluşturmaktadır. 
DEÜ FMD 23(67), 11-23, 2021

Genel jeolojik yapı ve sediman tașınım mekanizmasına bakıldığında, yüksek topoğrafya sunan alanlara yakın kesimlerde genel olarak iri daneli, düz veya düşük topografya sunan alanlarda ise ince daneli zeminlerin egemen olduğu bilinmektedir. Özellikle iri malzeme daha yakın kesimlerde, ince malzeme ise daha uzak noktalara kadar tașınabilmekte ve depolanmaktadır. Çalışma alanın jeolojik yapısı itibari ile Neojen birimler genel olarak ince taneli sediman birimlerini, şistler ise daha iri daneli zeminlerin üretimini sağlamaktadır. $\mathrm{Bu}$ bağlamda Neojen birimlerin egemen olduğu topoğrafyanın daha düşük eğime sahip olduğu güneydoğu kesimlerde ince ve kum ağırlıklı, alanın batı kesimleri ve yüksek eğimli alanlarda ise çakıl boyutunda zeminlerin baskın olduğu görülmektedir. Alanın orta kesimlerinde ise ince daneli zeminlerin egemen olduğu anlaşılmaktadır. Çalışma alanına ait bazı zemin karakteristik özellikleri: zemin sınıfı, porozite, doğal birim hacim ağırlık ve hidrolik iletkenlik değerleri 5, 10 ve 15 m derinlikler için Tablo 2'de sunulmuștur. Bu tabloda n poroziteyi, $\gamma_{\text {doğal }}$ doğal yoğunluğu $\left(\mathrm{gr} / \mathrm{cm}^{3}\right)$, $\mathrm{k}$ da hidrolik iletkenliği $(\mathrm{m} / \mathrm{s})$ temsil etmektedir. Proje sahasında alüvyon akiferin genelde kil ağırlıklı ve yer yer killi siltli çakıl ve kumlu seviyelerden oluştuğu belirlenmiștir.

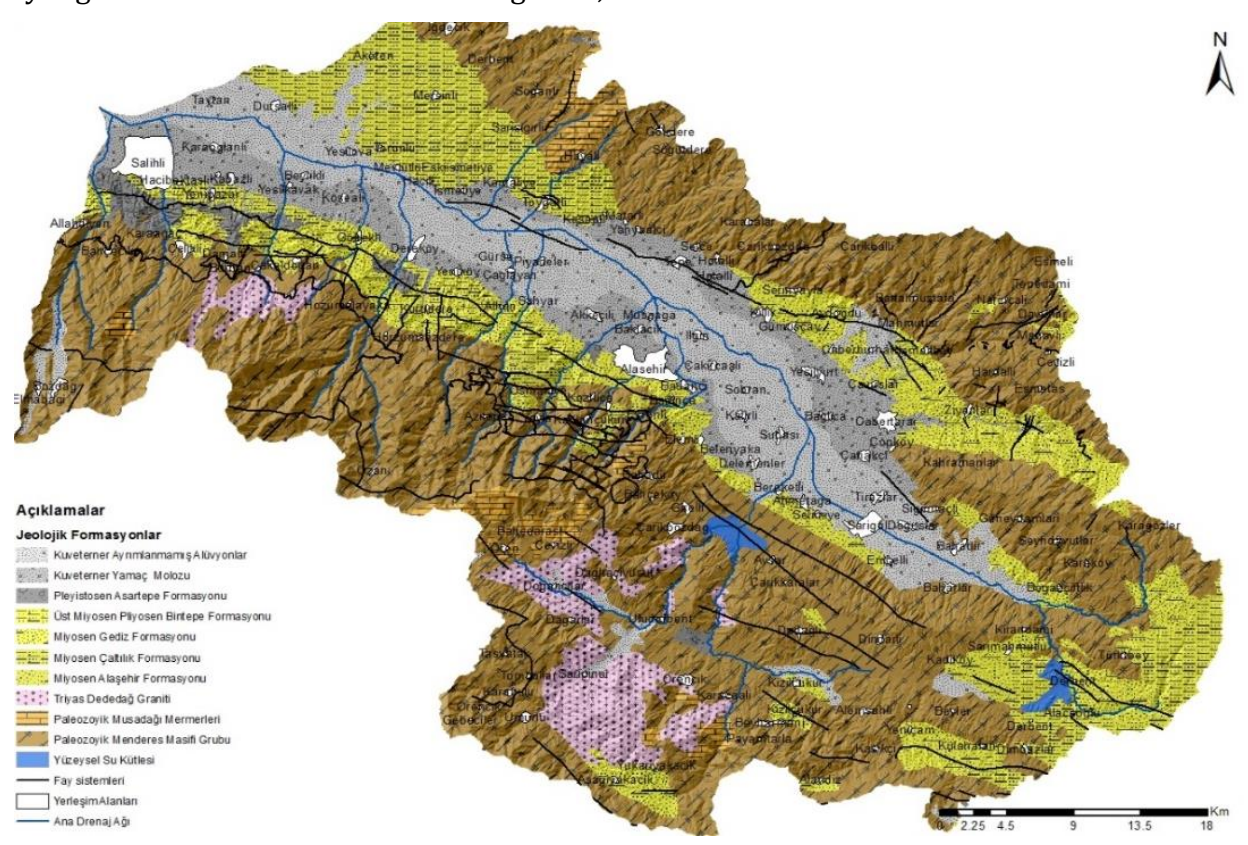

Şekil 6. Çalışma sahasının jeoloji haritası 
DEÜ FMD 23(67), 11-23, 2021

Tablo 2. Analiz Gerçekleștirilen Derinliklerdeki Zemin Karakterizasyonu

\begin{tabular}{|c|c|c|c|c|c|}
\hline Noktalar & Derinlik & Zemin Sinfi & $\mathrm{n}$ & $\begin{array}{c}\gamma_{\text {dogal }} \\
\left(\mathrm{gr} / \mathrm{cm}^{3}\right)\end{array}$ & $\begin{array}{c}\mathrm{k} \\
\mathrm{m} / \mathrm{sn}\end{array}$ \\
\hline \multirow{3}{*}{ Çağlayan (CY-1) } & $5 \mathrm{~m}$. & CL & & & 4.09E-07 \\
\hline & $10 \mathrm{~m}$. & GC & 0,28 & 2,09 & \\
\hline & $15 \mathrm{~m}$. & $\mathrm{sc}$ & 0,28 & 2,11 & $7.42 \mathrm{E}-06$ \\
\hline \multirow{3}{*}{ Çavuşlar (CV-1) } & $5 \mathrm{~m}$. & GP & & & $2.72 \mathrm{E}-06$ \\
\hline & $10 \mathrm{~m}$. & $\mathrm{CL}$ & 0,48 & 1,80 & 3.49E-06 \\
\hline & $15 \mathrm{~m}$. & CL & 0,48 & 1,98 & $3.84 \mathrm{E}-06$ \\
\hline \multirow{3}{*}{ Hacll (HC-1) } & $5 \mathrm{~m}$. & GC & & & $4.96 \mathrm{E}-06$ \\
\hline & $10 \mathrm{~m}$ & SC & & & $5.58 \mathrm{E}-06$ \\
\hline & $15 \mathrm{~m}$. & GC & & & $1.22 \mathrm{E}-05$ \\
\hline \multirow{3}{*}{ Tepeköy (TP-1) } & $5 \mathrm{~m}$. & $\mathrm{CL}$ & & 1,71 & 5.67E- 07 \\
\hline & $10 \mathrm{~m}$ & CL & 0,50 & 1,80 & $1.15 \mathrm{E}-06$ \\
\hline & $15 \mathrm{~m}$. & $\mathrm{SC}$ & & 1,75 & 4.57E-06 \\
\hline \multirow{3}{*}{ Tirazlı (TR-1) } & $5 \mathrm{~m}$. & $\mathrm{sc}$ & & & $1.70 \mathrm{E}-05$ \\
\hline & $10 \mathrm{~m}$ & $\mathrm{CH}$ & 0,43 & 1,91 & $3.46 \mathrm{E}-06$ \\
\hline & $15 \mathrm{~m}$. & $\mathrm{CL}$ & 0,42 & 1,93 & $1.73 \mathrm{E}-06$ \\
\hline
\end{tabular}

Zeminlerin geçirimlilikleri ise CL türü zeminlerin geçirimsiz, killi çakıl ve kumların ise düşük geçirimli oldukları görülmektedir. Zeminlerin genel karakteristik özellikleri Tablo 2'de sunulmuştur. Kuyu profili boyunca geçirgenlik testleri 2 m'lik zonlar içerisinde yapılmakta olup bu aralıkta zemin sınıfları oldukça değişkenlik göstermektedir. Zemin nem sensörü ise $10 \mathrm{~cm}$ catal uzunluğunun batırıldığı derinlikteki zemin sınıfı ve geçirgenliği büyük önem taşımaktadır. $\mathrm{Bu}$ nedenle Tablo 2'de sunulan geçirgenlik değerleri $2 \mathrm{~m}$ kalınlığındaki zemin grubunu temsil etmektedir. Ayrıca, daha önce uygulanan yöntemlerde zemin nem sensörleri en fazla $2 \mathrm{~m}$ derinliğe kadar uygulanmış olup, bu çalışmada ise oldukça derin sondajlar içerisinde gerçekleştirilmiştir.

\subsection{Nem ölçümü ve havza beslenimi}

Uzun bir arazi çalışması olan projede 5 noktada ve 3 farklı derinliklerde olmak üzere 15 adet zemin nem sensörleri konumlandırılmış ve verileri kullanılmıştır. Ancak her şey planlandığı gibi gitmemiștir. $\mathrm{Bu}$ sensörlerden biri olan Tepeköy 15 m'deki zemin nem sensörü arızalanmıș ve kablosu ile birlikte çıartılmıș ve tamir için ilgili firmaya gönderilmiştir. Diğer bir sensör noktası olan Tırazlar noktasında tüm cihazlar tarla sürerken kuyular tahrip edilmiș ve tüm cihazlar kuyu ve toprak altında kalarak kullanılamaz hale gelmiştir. $\mathrm{Bu}$ nedenle bu noktada Nisan sonrası veriler alınamamıștır. Tırazlar noktasındaki veriler bir ay eksiktir. Şekil 7'de Çağlayan zemin nem sensörlerinin zamana bağlı olarak değişimi verilmiştir. Burada bazı sensörlerde başlangıç kalibrasyonu yapılmasına rağmen yüksek başlamış ve zamana bağlı olarak düşmüștür. Bunun en önemli nedeni sulu sistem ile açlan kuyularda hapsolan sondaj çamur suyunun etkisidir. Bu sistemler için genel olarak kuru sistem açılması gerekmektedir. Ancak 5, 10 ve $15 \mathrm{~m}$ derinliklere kuru sistem açlması olanaksızdır. $\mathrm{Bu}$ nedenle bu tip bir eğri sunan verilerde normalizasyon yapılmıștır. Yani genel ortalaması ve standart sapması bulunarak normalize edilmiş ve çok değişkenlik sunan veriler normalize edilerek kullanılmıștır. Sahada konumlandırılan zemin nem grafikleri Şekil 7 ile 11 'de sunulmuștur. Bu grafiklerdeki yağıșların olduğu ayki değişimler için ilgili aydaki tüm su içeriği istatistiği çıkartılmış, minimum ve maksimum değerler belirlenerek bu değerler kullanılmıștır. Aylık maksimum ve minimum değerler çıkartılarak aylık su içeriği değișimleri hesaplanmıştır (Tablo 3). Daha sonra ise yağıșlı dönemdeki izleme noktası bazındaki her bir noktadaki düșey su içeriği değişimleri Bağıntı 1 ile verilen formüle göre toplanarak toplam su içeriği değișimi hesaplanmıș ve yağıșa göre oranı ele alınarak beslenim miktarı hesaplanmıştır.

Cavuşlar (CV-1) zemin nem noktasında farklı derinliklerde yer alan farklı zemin gruplarına göre eğride değişkenlik sunmaktadır (Şekil 8). Genel olarak ince daneli zeminlerde yüksek ve sürekli artan veya azalan eğri sunarken iri daneli zeminlerde ise çok değișkenlik sunmamaktadır. Bunun nedeni de zeminlerin geçirimliliği ile açıklanmaktadır. $14 \mathrm{~m}$ derinlikteki zeminin geçirimli özelliğine sahip ağırlıkla kum olması tabakaya giren zemin neminin beklemeden düșey yönde hareket ettiğini ifade etmektedir. 8 m'deki zemin neminde Mayıs ayından hızla yükseldiği izlenmektedir. Burada muhtemel kuyu içerisine yanal olarak su giriși ile zeminde su depolanması olduğunu düşünülmektedir.

Hacılı (HC-1) zemin nem sensörleri her biri farklı bir değişkenlik sunmaktadır. Özellikle $5 \mathrm{~m}$ 'deki zemin sensöründe kaydedilen zemin nemlerinin 
DEÜ FMD 23(67), 11-23, 2021

çok düșük olduğu ve zamana bağlı olarak arttığı görülmektedir (Sekil 9). Burada iri daneli zemin olan alanda alttaki geçirimsiz tabakanın etkisi ile tünek akifer gibi davrandığı düşünülmektedir. 15 m'deki ise çok fazla bir değişkenlik sunmadığı görülmektedir. Ağırlıkla ince daneli zeminlerden oluşan bölgede 15 m'lerde iri daneli zeminler kesilmiştir.

Tepeköy (TP-1) zemin nem sensörünün 15 m'deki kısmı arızalanması nedeni ile 5 ve $10 \mathrm{~m}$ olan veriler değerlendirilmiştir (Şekil 10). Burada $10 \mathrm{~m}$ derinlikte iri daneli zeminlerin egemen olması nedeni ile dalgalı bir veri olduğu görülmektedir. Geçirimsiz killerden iri daneli zeminlere süzülen nem oranı hızla uzaklașması nedeni ile dalgalı bir veri sunduğu düşünülmektedir.

Tırazlar (TP-1) nolu izlem noktasında yüzeyden 8 m'ya kadar kumlu zeminler, 8 m'den itibaren ise kum bantları içeren kil ağırlıklı bir zemin sunduğu görülmektedir (Şekil 11). Bu bağlamda eğriler birbirine benzer bir değișim sunmaktadır. Yukarı kesimde zemin nemi çok düşük iken 15 m'de oldukça yüksektir. Burada su derinliği 30 m ve daha aşağısında olduğu dikkate alındığında muhtemel 15 m'de altında geçirimsiz bir tabakanın varlığını ve buradaki zeminlerin tünek akifer gibi davrandığı düșünülmektedir.
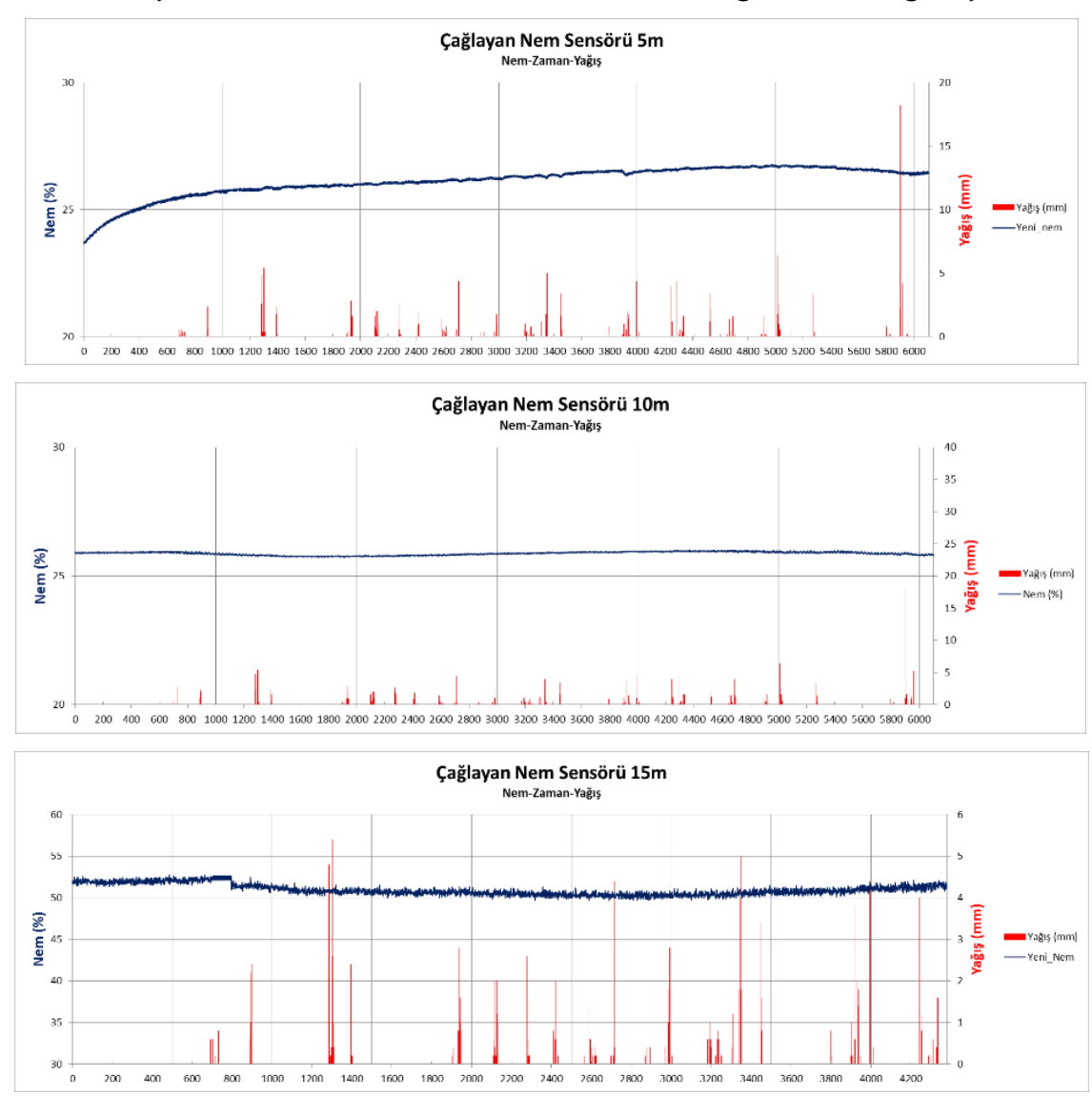

Şekil 7. Çağlayan (CY-1) zemin nem sensörleri su içeriği değişimi 
DEÜ FMD 23(67), 11-23, 2021

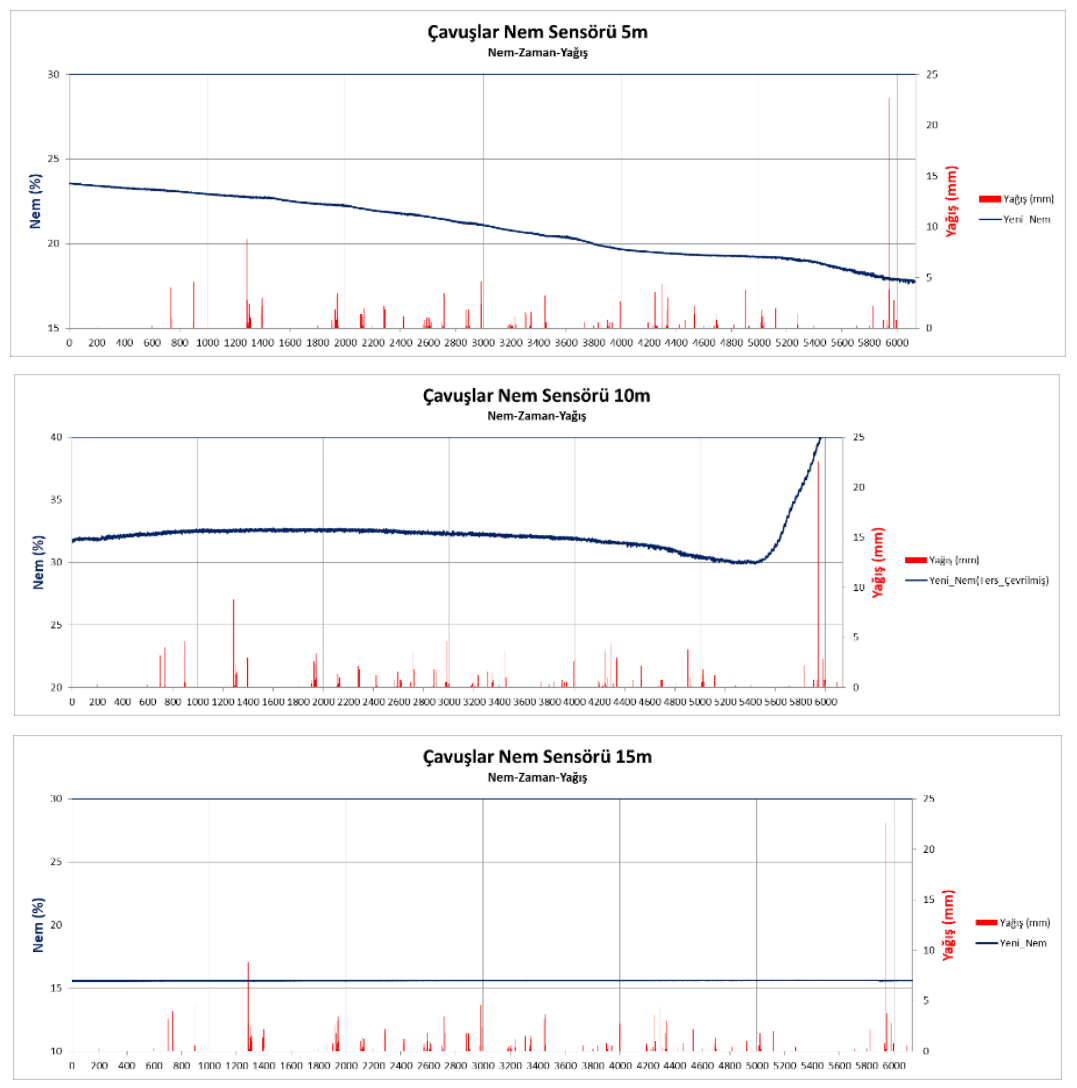

Şekil 8. Çavuşlar (CV-1) zemin nem sensörleri su içeriği değişimi
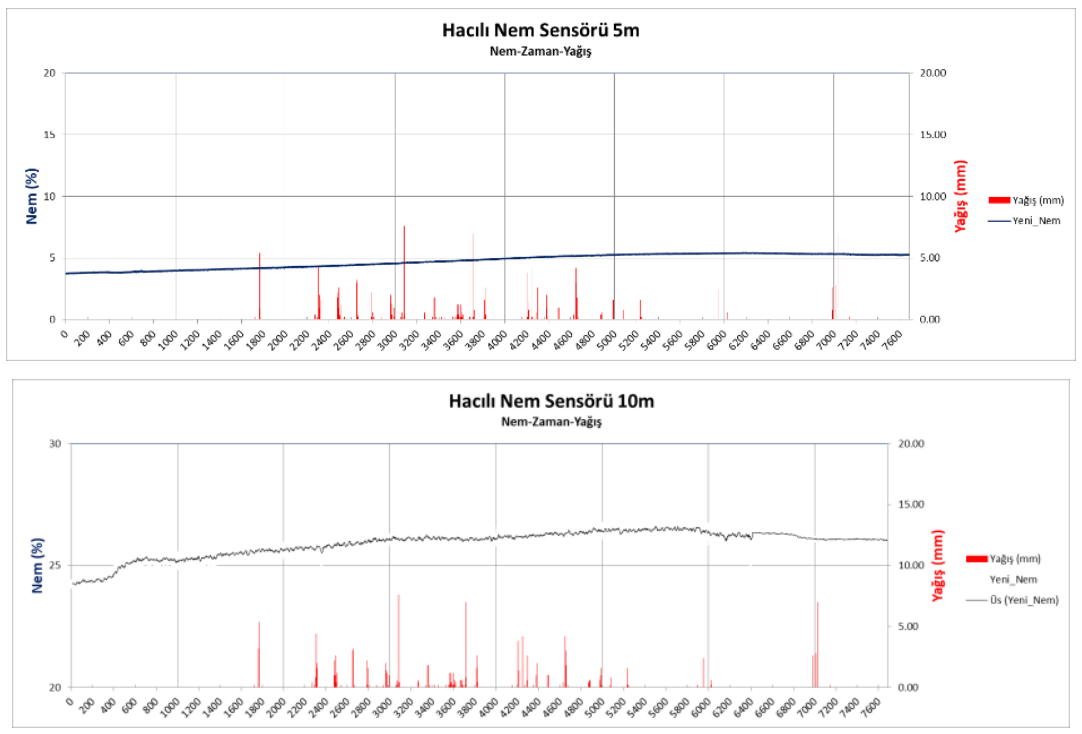
DEÜ FMD 23(67), 11-23, 2021

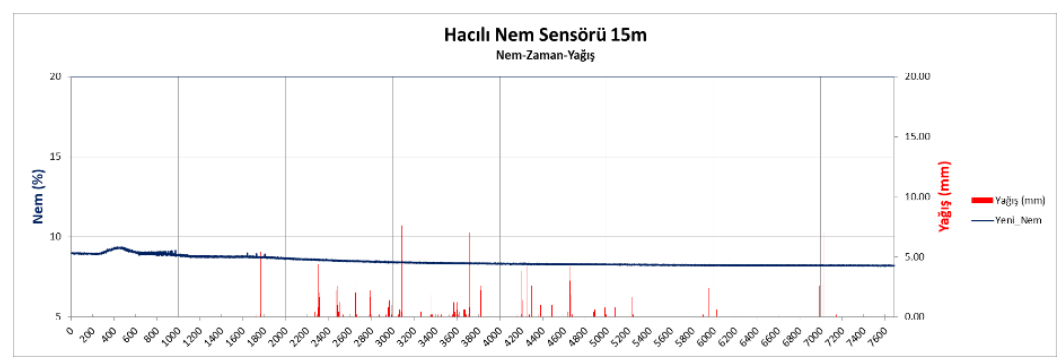

Şekil 9. Hacılı (HC-1) zemin nem sensörleri su içeriği değișimi [22]
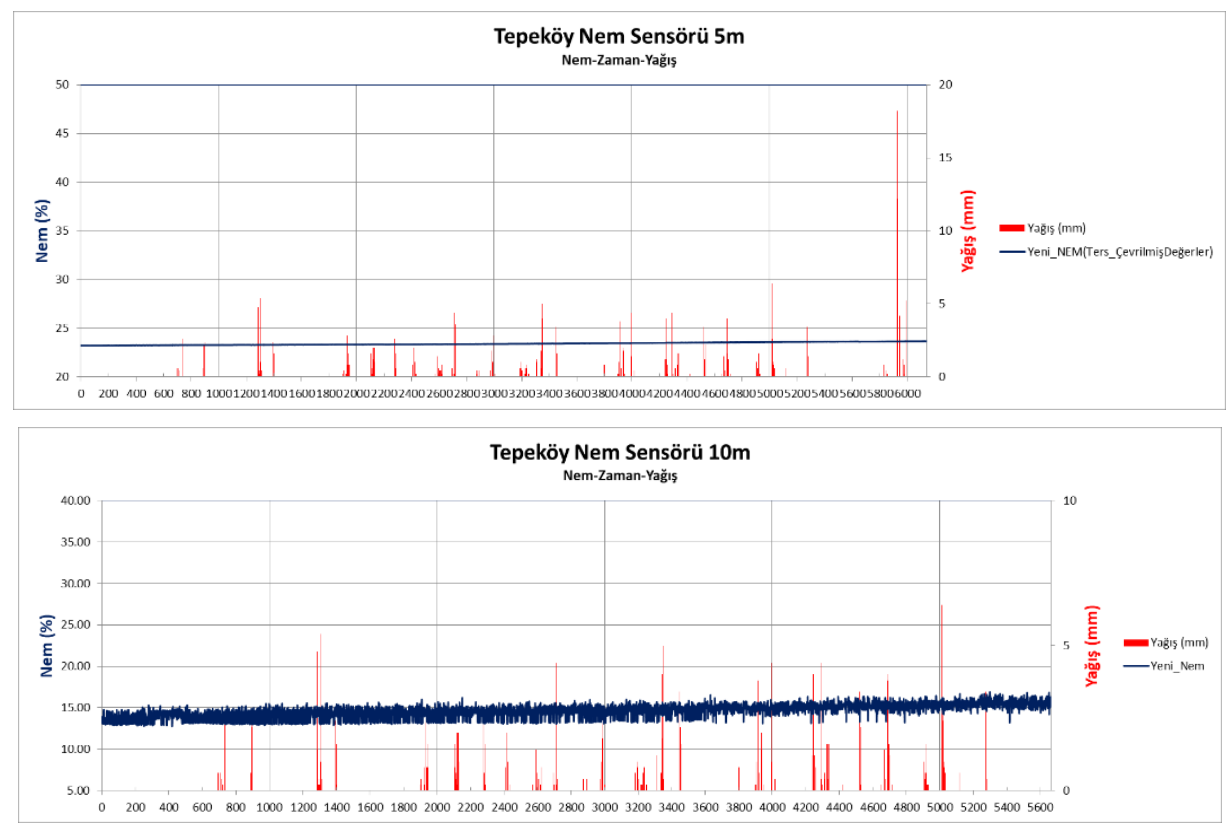

Şekil 10. Tepeköy (TP-1) zemin nem sensörleri su içeriği değișimi

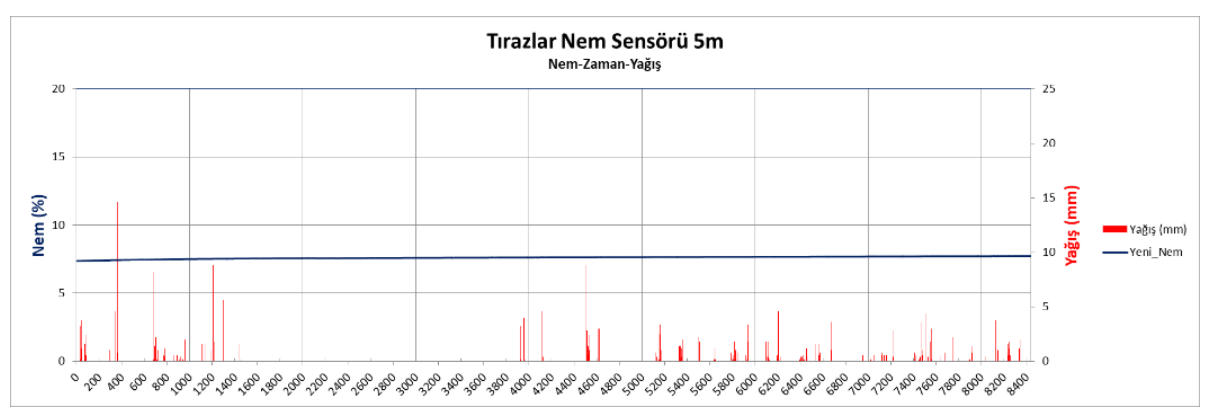


DEÜ FMD 23(67), 11-23, 2021

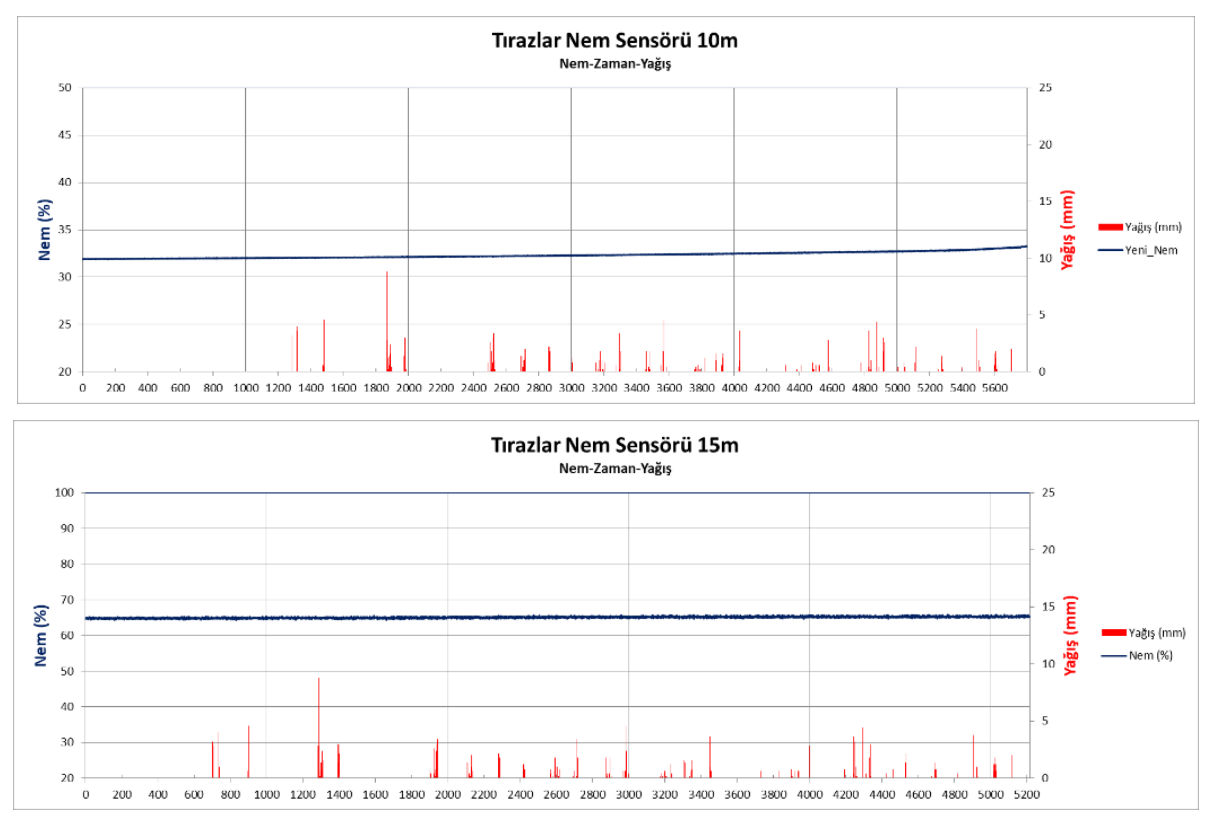

Şekil 11. Trazlar (TR-1) zemin nem sensörleri su içeriği değiş̧imi

Tablo 3. Aylık Bazda toplam su içeriğindeki değişimler ve aylık toplam yağış verileri

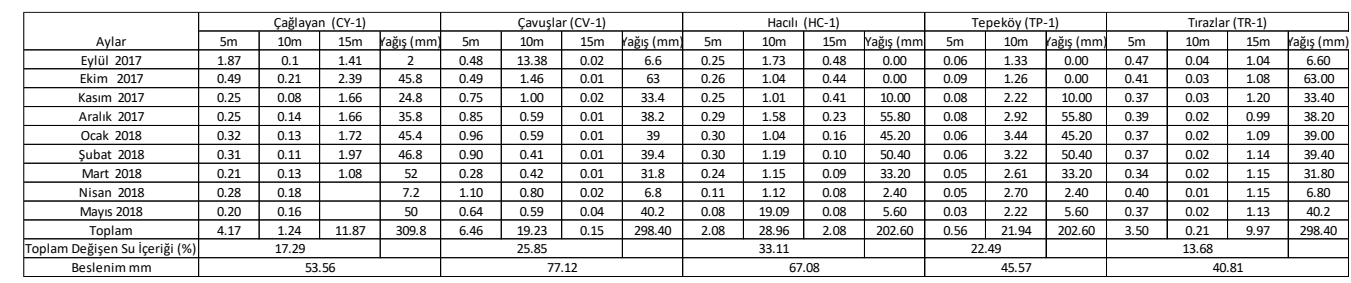

Mevcut verilerden elde edilen aylık değișen zemin nem miktarları her sensör için hesaplanmıştır. Daha sonra ise farkl derinliklerde kaydedilen değișen zemin nem oranları toplanarak toplam değişen oran elde edilmiștir. $\mathrm{Bu}$ oran yağıștan sonra zemin nemindeki değişim olarak değerlendirilmiş ve kurak döneme göre artış olarak kaydedilmiştir. Yüzde olarak belirlenen zemin nem değișimleri yağıșla çarpılarak mm olarak beslenme miktarı elde edilmiştir. Turazlar (TR-1) sensörlerindeki eksik ay olan Mayıs verisi son üç ay ortalama zemin nem değişimi baz alınarak tamamlanmıştır. $\mathrm{Bu}$ beslenme miktarını çok değiștirmemekle birlikte diğer verilerle korelasyona tabi tutulması açısından eksik verinin tamamlanmasına karar verilmiștir. $\mathrm{Bu}$ bağlamda ele alındığında vadoz zon bölgesindeki zemin nemi değişiminden yola çıkarak elde edilen beslenme miktarları minimum 40,81 ile maksimum 77,12 mm olacak şekilde, ortalama olarak da 56,83 mm hesaplanmıştır (Tablo 4). En düșük değer Tırazlar, en yüksek değer ise Çavuşlar bölgesinden elde edilmiştir. Burada zemin sınıfı ile karşılaştırıldığında Çavuşlar bölgesi iri daneli zeminlerin egemen olduğu alanlar, Tirazlar ise ince daneli zeminlerin ve kum, silt gibi kötü derecelenmiș zeminlerin olduğu alanları yansıtmaktadır. Bu bağlamda zeminlerin geçirimliliğine göre ele alındığında uyumlu değerler elde edilmiştir. Elde edilen ortalama yağışa oranla zemin nemindeki değișim \%22,48'sine denk gelmektedir. Alüvyon akifer üzerine düșen yağışın yaklaşık \%22,48'i doğrudan yeraltısuyuna beslenme olarak yansımaktadır. Burada elde edilen bu değerin 
DEÜ FMD 23(67), 11-23, 2021

sadece yüzey süzülmesi olduğu dikkate alınmalıdır.

Tablo 4. Zemin Nem Sensörleri ile beslenimi ve yağış ile karşılaştırılması

\begin{tabular}{lcc}
\hline Noktalar & $\begin{array}{c}\text { Beslenim - Nem } \\
\text { Sensörleri (mm) }\end{array}$ & $\begin{array}{c}\text { Zemin Nemine Etki } \\
\text { Eden Yağıșa Oranı (\%) }\end{array}$ \\
\hline $\begin{array}{l}\text { Çağlayan } \\
\text { (CY-1) }\end{array}$ & 53,56 & 17,29 \\
\hline $\begin{array}{l}\text { Çavuşlar } \\
\text { (CV-1) }\end{array}$ & 77,12 & 25,84 \\
\hline $\begin{array}{l}\text { Hacılı } \\
\text { (HC-1) }\end{array}$ & 67,08 & 33,11 \\
\hline $\begin{array}{l}\text { Tepeköy } \\
\text { (TP-1) }\end{array}$ & 45,57 & 22,49 \\
\hline $\begin{array}{l}\text { Tirazlı } \\
\text { (TR-1) }\end{array}$ & 40,81 & 13,68 \\
\hline Ortalama & 56,83 & 22,48 \\
\hline
\end{tabular}

\section{Tartışma ve Sonuç}

Son yıllarda zemin nem değișimi elektronik sistemlerle zamana bağlı olarak izlenerek ölçümler yapılmakta ve yağış ile ilișkilendirilebilmektedir [24]. Bu bağlamda problar belli derinliklere (0,5-3 m) konumlandırılarak tarımsal sulama suyunun süzülme oranını veya yağıșın toprak nemindeki etkisini izlemek için kullanılmaktadır. $\mathrm{Bu}$ çalışma ise ilk kez çok kalın bir vadoz zona sahip (5-30m arasında değişmekte) çalışma alanında 5,10 ve 15 m'ler gibi çok derin sayllabilecek zonlarda uygulanmıș ve beslenim değerleri hesaplanmış ve ortalama olarak $56,83 \mathrm{~mm}$

\section{Teşekkür}

$\mathrm{Bu}$ çalışma Türkiye Bilimsel ve Teknolojik Araştırma Kurumu (TÜBİTAK) tarafından 115 Y065 nolu proje kapsamında desteklenmiştir.

\section{Kaynakça}

[1] Margat, J., Gun V.D.J. 2013. "Groundwater Around The World", CRC Press/Balkema.

[2] Custodio, E. 2002. "Aquifer overexploitation: what does it mean?" Hydrogeology Journal. 10:254-277.

[3] Zektserr, S.I, Everett, L.G. 2004. "IHP-VI, SERIES ON GROUNDWATER NO. 6. Layout and typesetting by Marina Rubio", 93200 Saint-Denis

[4] Salameh E. 2008. "Over-exploitation of groundwater resources and their environmental and socioeconomic implications: the case of Jordan". Water International. 33:1.

[5] Günay, G. 2011. "Türkiye'nin Yüzey Suları ve YeraltıSuları Potansiyeli, Bilim ve Aklın Aydınlığında Eğitim", S. 132, ss. 56-60. olarak bulunmuștur ve yine ortalama olarak zemin nemine etki eden yağıșa oranı da \%22,48 olarak hesaplanmıştır (Tablo 4). Yapılan çalışma sonucunda yöntemin limitasyonları aşağıda sıralanmıștır.

- Zemin nem sensörleri yeraltısuyunun sı̆̆ olduğu alanlarda uygulanmalıdır $(<10 \mathrm{~m})$.

- Sensörler mutlaka yeraltısuyu buharlașma zonunun altında yer almalıdır.

- Sensörler için açllacak kuyuların susuz açılması gerekmektedir.

- Sensörlerin ilgili derinlikteki zemine iyi konumlandırılması gerekmektedir. Aksi takdirde, kuyu içi suyundan etkilenmektedirler.

- En az iki sensör ile bir noktada izleme yapılmalıdır.

- Yağıș, sulama suyu ve yüzeysel sulardan süzülme oranları için ilgili kaynaklara yakın izleme yapılabilecek özelliğe sahip olmalıdırlar.

Proje kapsamında açılan sondajların, sulu sistem açılması nedeni ile, başlangıç zemin nem miktarları yüksek elde edilmiștir. Bu veriler, tüm veri alındıktan sonra normalize edilmiștir. Ayrıca, proje kapsamında öngörülen derinliklerin çok fazla olduğu ve bu derinliklere cihazın konumlandırılması oldukça zor olmuştur. Bu bağlamda, bu sistemlerin daha sığ alanlarda kullanılması önerilmektedir.

[6] DSİ, 2000. " Revize Hidrojeolojik Etüdler Kapsamında Küçük Menderes Havzası Yeraltısularının İncelenmesi ve Yönetimi, Devlet Su İşler Genel Müdürlüğü, Ankara

[7] DSİ 2014. DSİ 02 Bölge Gediz Havzası Yeraltısuyu Planlaması Hidrojeolojik Etüd Raporu, DSİ Ankara

[8] Gündüz, O., Şimșek, C. 2011. "Influence of Climate Change on Shallow Groundwater Resources: The Link Between Precipitation and Groundwater Levels in Alluvial Systems" Climate Change and its Effects on Water Resources, NATO Science for Peace and Security Series C: Environmental Security 3,

[9] SYGM, 2015. Yeraltısuyu Kütlelerinin Belirlenmesi, Su Yönetimi Genel Müdürlüğü Rehber Dökümanı, Ankara

[10] TÜBİTAK-MAM, 2013. "Havza Koruma Eylem Planlarının Hazırlanması Projesi, Gediz Havzası Proje Taslak Raporu", Proje No: 5118601, Türkiye Bilimsel ve Teknolojik Araștırma Kurumu Marmara Araştırma Merkezi Çevre ve Temiz Üretim Enstitüsü, Gebze, Kocaeli, 449s. 


\section{DEÜ FMD 23(67), 11-23, 2021}

[11] YASKBKY, 2012. "Yeraltısularının Kirlenmeye Bozunmaya Karşı Korunması Hakkındaki Yönetmelik". 28257 Nolu Resmi Gazete, Ankara.

[12] İTASHY, 2013. İnsani Tüketim Amaçlı Sular Hakkında Yönetmelik Hakkında Değişiklik Yapılmasına Dair Yönetmelik. 2858 Nolu Resmi Gazete.

[13] Healy, R.W. 2010. "Estimating of Groundwater. Cambridge University Press. The Edinburg Building", Cambridge, UK

[14] Scanlon, B. R., Healy, R. W., \& Cook, P. G. 2002. Choosing appropriate techniques for quantifying groundwater recharge. Hydrogeology Journal, 10(1) 18-39.

[15] Weight, W.D. 2008 "Hydrogeology Field Manual". Second Edition. Mc Graw Hill Companies. USA.

[16] Leaney, F., Crosbie, R., O'Grady, A., Jolly, L., Gow, L., Davies, P., Wilford J., Kilgour. P. 2011. " Recharge and Discharge Estimation in Data Poor Areas Scientific Reference Guide, Avustralian Goverment. National Water Comission. CSIRO": Water for a Healthy Country National Research Flagship. 61 pp.

[17] Şimşek, C., Baba, A., Aksoy, N., Demirkıran, Z., Hasözbek, A., Tayfur, G., Kumanlıŏlu, A., Durukan, S. Demirkesen, A.C., Murathan, A., Çağıran, Ö. Akdeğirmen, Ö., Tonkul, S. 2017. Investigation of Groundwater Recharge Mechanism in Alaşehir Plain: From Physical Characterization to Modelling. 2nd Regional IWA Symposium on Water, Wastewater and environment, Çeşme, İzmir

[18] Uytun, A., Pekey, B., Kalemci, M. 2013. Toprak Nemi Ölçümleri, 8. Ulusal Ölçübilim Kongresi, 26-28 Eylül, Gebze

[19] Kumar S. 2013. "Estimation of Groundwater Recharge Using Soil Moisture Modelling: Experiments in Berambadi Catchment". Department of Civil Engineering Indian Institute of Science. Bangalore

[20] Oliver C.O, Smetten K, Kranz M, Mayer K. 2004. Field Testing a Wireless Sensor Network for Reactive Environmental Monitoring. Technical Report UWACSSE-04-003. Available http://www.csse.uwa.edu.au/research/Technical Reports/UWA-CSSE-04-003/Report-04-003.pdf

[21] Durukan, S., Sarıkaya, E., Şimşek, C., Demirkesen, A 2018. Alașehir (MANISA) Havzası Zemin Karakterizasyonunun Belirlenmesi /The Soil Profile Characterization of Alașehir Basin (Manisa). Uluslar arası Katılımlı 71. Jeoloji Kurultayı, Ankara

[22] Sophocleous, M.A. 1991. Combining The Soilwater Balance And Water-Level Fluctuation Methods To Estımate Natural Groundwater Recharge: Practıcal Aspects. Journal of Hydrology, 124: 229-241.

[23] Delin G.N, Herkelraht . 2005. Use Of Soil Moisture Probes To Estimate Ground Water Recharge At An Oll Spill Site. Journal of The American Water Resources Association
[24] Herkelrath, W. N., Delin, G. N. 2001. Long-term monitoring of soil-moisture in a harsh climate using reflectometer and TDR probes. US Geol. Surv., Menlo Park, $C A$. 